\title{
Human leptin forms complexes with $\alpha 2$-macroglobulin which are recognized by the $\alpha 2$-macroglobulin receptor/low density lipoprotein receptor-related protein
}

\author{
Gerd Birkenmeier $^{1}$, Ingrid Kämpfer ${ }^{2}$, Jürgen Kratzsch ${ }^{3}$ and Wolfgang Schellenberger ${ }^{1}$ \\ ${ }^{1}$ Institute of Biochemistry, ${ }^{3}$ Institute of Clinical Chemistry and Pathobiochemistry and ${ }^{2}$ Clinic of Nuclear Medicine of the Medical Faculty, \\ University of Leipzig, Germany
}

(Correspondence should be addressed to G Birkenmeier, Institute of Biochemistry, University of Leipzig, Liebigstrasse 16,04103, Leipzig, Germany)

\begin{abstract}
Objective: To identify binding proteins of leptin in human plasma.

Methods: Binding was evaluated by electrophoresis, size exclusion chromatography (SEC), Western blotting, and radioisotope labeling. Quantification of leptin and the different forms of $\alpha 2$-macroglobulin $(\alpha 2-\mathrm{M})$ was performed by ELISA.

Results: Leptin interacts with the proteinase inhibitor, $\alpha 2-\mathrm{M} .{ }^{125}$ I-labeled leptin specifically binds to the transformed inhibitor, which arises by reaction with proteinases or with reactive primary amines. No leptin binding was observed to the native $\alpha 2-\mathrm{M}$, which abundantly occurs in plasma. The complex formation between leptin and $\alpha 2-\mathrm{M}$ was found to proceed within minutes and was stable, as it resisted separation by SEC and electrophoresis. The $K_{\mathrm{d}}$ of the complex was $2.14 \pm 0.78 \mu \mathrm{mol} / \mathrm{l}$. Complex formation with transformed $\alpha 2-\mathrm{M}$ did not interfere with the immunological determination of leptin in plasma. The leptin- $\alpha 2-\mathrm{M}$ complex was found to be recognized by the $\alpha 2-\mathrm{M}$ receptor/low density lipoprotein receptor-related protein. By computer analysis, a simple model is presented showing that the degree of transformation of $\alpha 2-\mathrm{M}$ may significantly influence the leptin concentration in blood. Conclusions: The proteinase inhibitor, $\alpha 2-\mathrm{M}$, may act as a leptin-binding protein in human plasma. Binding of leptin to transformed $\alpha 2-\mathrm{M}$ and its rapid clearance by the $\alpha 2-\mathrm{M}$ receptor may significantly influence the bioavailability of leptin in human plasma.
\end{abstract}

European Journal of Endocrinology $139224-230$

\section{Introduction}

Leptin $(16 \mathrm{kDa})$, a product of the obese gene, is secreted from adipose tissue and it is suggested that in mice it acts on the central nervous system to regulate body weight through the control of appetite and energy expenditure $(1,2)$. Its role in man may be more complex, and remains to be elucidated. One major effect of leptin may be to inhibit synthesis and release of the hypothalamic neuropeptide $\mathrm{Y}$, which increases food intake, decreases thermogenesis, and increases levels of insulin in plasma (3).

In rodents and humans the level of leptin is highly correlated with the size of the body fat mass. Recent data suggest that in obesity it is not the absence of leptin but leptin resistance which may be the cause of this conditions (4). In blood, leptin is thought to be bound to other proteins (5-7). Such binding proteins, known for a number of growth factors and cytokines, may alter the clearance of these biomolecules, influencing their bioavailability or protecting them from degradation (8). To understand the physiology of circulating leptin, it is important to determine its interaction with these circulatory components.

$\alpha 2$-Macroglobulin $(\alpha 2-\mathrm{M})$, a proteinase inhibitor in blood and tissue, is known to act as such a binding protein for numerous cytokines and growth factors (9). Recently, we have shown that $\alpha 2-\mathrm{M}$ is also involved in binding and transport of human growth hormone (10). These biologically important polypeptides mainly bind to transformed $\alpha 2-\mathrm{M}\left(\alpha 2-\mathrm{M}_{\mathrm{t}}\right)$, which is the receptorrecognizable form of the inhibitor. The receptor of $\alpha 2-\mathrm{M}$ ( $\alpha 2-\mathrm{M}-\mathrm{R})$ was found to be identical to the low density lipoprotein receptor-related protein (LRP) $(11,12) . \alpha 2-$ M-R/LRP is known to confer binding and endocytosis of multiple ligands such as $\alpha 2-\mathrm{M}_{\mathrm{t}}$, lipoproteins (13) and diverse proteinase-proteinase inhibitor complexes (14). The objective of the present study was to analyze the binding proteins for circulating leptin. Such plasma components capable of interacting with leptin have been suggested, but their identities have not been elucidated up to now. We identified $\alpha 2-\mathrm{M}$ as such a leptin-binding factor in human plasma. We provide evidence that leptin binds only to $\alpha 2-\mathrm{M}_{\mathrm{t}}$ but not to the 
native inhibitor. The complex was found to be recognized by $\alpha 2-\mathrm{M}-\mathrm{R} / \mathrm{LRP}$.

\section{Subjects and methods}

\section{Patients}

Fresh blood was obtained from the Clinic of Internal Medicine of the University of Leipzig from a healthy, female volunteer (age 23 years; body mass index $20.2 \mathrm{~kg} / \mathrm{m}^{2}$; leptin concentration $6.21 \mathrm{ng} / \mathrm{ml}$ ).

\section{Reagents}

Recombinant human leptin and rabbit anti-human leptin antibodies were purchased from PeproTech, Inc. (Rocky Hill, NY, USA). Purified, native $\alpha 2-\mathrm{M}$, purified $\alpha 2-\mathrm{M}-\mathrm{R} / \mathrm{LRP}$, and horse radish peroxidase (HRP)conjugated immunoglobulin (Ig) of rabbit anti-human $\alpha 2-\mathrm{M}$ were obtained from BioMac GmbH (Leipzig, Germany).

\section{Preparation of samples}

Citrated blood was centrifuged to remove blood cells. Unless immediately analyzed, the plasma was kept at $-20{ }^{\circ} \mathrm{C}$. No serum was used for analysis. This was to guarantee that more than $99 \%$ of $\alpha 2-\mathrm{M}$ in the plasma was in the native form. In vitro transformation of isolated $\alpha 2-\mathrm{M}$ and $\alpha 2-\mathrm{M}$ in plasma was achieved by treatment of the samples with $200 \mathrm{mmol} / \mathrm{l}$ methylamine (MA) (Sigma Chemical Co., St Louis, MO, USA) for $4 \mathrm{~h}$ at room temperature. The resulting samples, designated as $\alpha 2-\mathrm{M}-\mathrm{MA}$ and MA-plasma respectively, were extensively dialyzed against PBS $(50 \mathrm{mmol} / \mathrm{l}$ sodium phosphate, $150 \mathrm{mmol} / \mathrm{l} \mathrm{NaCl}, \mathrm{pH} 7 \cdot 4)$.

\section{Quantification of total and $\alpha \mathbf{2}-M_{t}$}

The concentrations of total and $\alpha 2-\mathrm{M}_{\mathrm{t}}$ were measured by ELISA using the test kits MacroNat and MacroTrans respectively, obtained from BioMac $\mathrm{GmbH}$.

\section{Determination of leptin}

The concentration of leptin in plasma was determined immunologically using the Human Leptin RIA Kit obtained from BioTrend Chemikalien GmbH (Köln, Germany).

\section{Radiolabeling of leptin}

Recombinant leptin $(1 \mu \mathrm{g})$ was labeled with $\left[{ }^{125} \mathrm{I}\right] \mathrm{NaI}$ (Amersham, Braunschweig, Germany) according to Hunter and Greewood's chloramine-T method (15). The specific activity of ${ }^{125}$ I-leptin was 200000 c.p.m./ ng. The sample was stored at $4{ }^{\circ} \mathrm{C}$ in PBS containing $2 \%$ BSA for stabilization.

\section{Binding studies by size exclusion chromatography (SEC)}

Mixtures of ${ }^{125}$ I-leptin with plasma and MA-plasma were separated by SEC, using a Superdex 200 column $(16 \mathrm{~mm} \times 60 \mathrm{~mm})$ from Pharmacia (Uppsala, Sweden). The column was equilibrated with PBS at a flow rate of $1 \mathrm{ml} / \mathrm{min}$. The sample volume was $200 \mu \mathrm{l}$. Fractions of $1 \mathrm{ml}$ were collected. As a control, the tracer was chromatographed in the presence of $2 \%$ BSA under the same conditions.

\section{Electrophoresis}

Resolution of native $\alpha 2-\mathrm{M}$ and $\alpha 2-\mathrm{M}_{\mathrm{t}}$ was achieved by rate electrophoresis on $5 \%$ polyacrylamide slab gels as previously described (16). Polyacrylamide gel electrophoresis (PAGE) was performed in $3-15 \%$ polyacrylamide slab gel gradients using Tris-glycine buffer. Sodium dodecyl sulfate (SDS) electrophoresis was done in the same gradient gels according to Laemmli (17). The gels were stained with Coomassie Brilliant Blue R 250. In some experiments, the gels were dried and exposed at $-80^{\circ} \mathrm{C}$ to Hyperfilm-MP (Amersham).

\section{Receptor binding studies}

Titer plates were coated with purified $\alpha 2-\mathrm{M}-\mathrm{R} / \mathrm{LRP}$ $(2 \mu \mathrm{g} / \mathrm{ml})$. After washing, the plates were incubated with increasing concentrations of ${ }^{125}$ I-leptin- $\alpha 2-\mathrm{M}$ MA complex, which had been made by reacting $100 \mu \mathrm{g}$ of $\alpha 2$-M-MA with $5 \mathrm{ng}{ }^{125} \mathrm{I}$-leptin at $37^{\circ} \mathrm{C}$ for $30 \mathrm{~min}$. Further processing of the plates is described in the legend of Fig. 5.

\section{Computer modeling}

The impact of the leptin- $\alpha 2-M$ interaction on the clearance of leptin was analyzed in terms of a steady state model. The dependence of stationary leptin concentration on the rate of transformation of $\alpha 2-\mathrm{M}$ was analyzed using the software tool GEPASI (18).

\section{Results}

When human recombinant ${ }^{125}$ I-leptin was incubated with plasma at $37^{\circ} \mathrm{C}$ for $1 \mathrm{~h}$ and analyzed by SEC, the main peak of radioactivity (peak II) represented unbound or free leptin when compared with the elution profile of tracer alone (Fig. 1). In the case of plasma treated with MA, an additional peak of radioactivity (peak I) appeared, corresponding to the elution position of human $\alpha 2-\mathrm{M}$ (arrow). Approximately $30 \%$ of the total radioactivity applied was found within this peak. Treatment of plasma with the reactive MA causes transformation of $\alpha 2-\mathrm{M}$ (16). The transformed $\alpha 2-\mathrm{M}$ ( $\alpha 2-\mathrm{M}-\mathrm{MA})$ can easily be separated from native inhibitor by rate electrophoresis (Fig. 2). In this 


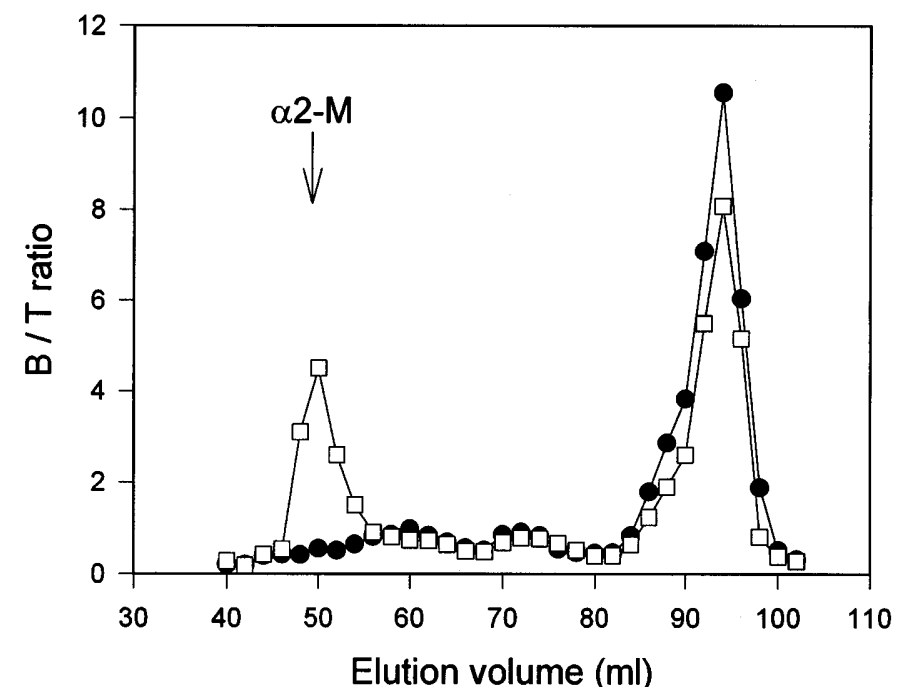

Figure 1 Distribution of ${ }^{125}$-leptin in plasma and MA-treated plasma analyzed by SEC. ${ }^{125}$ I-leptin $(60000$ c.p.m.) was dissolved in $50 \mu \mathrm{l}$ PBS and incubated at $37^{\circ} \mathrm{C}$ for $1 \mathrm{~h}$ with

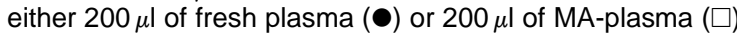
and then separated on a Superdex 200 column. The radioactivity in the fractions (ordinate) was measured and related to the total radioactivity of the sample to determine the $B / T$ ratio ( $B$, bound radioactivity; $T$, total radioactivity). The elution volume of the column is depicted on the abscissa of the graph. experiment, radiolabeled leptin was incubated with purified $\alpha 2-\mathrm{M}$ and $\alpha 2-\mathrm{M}-\mathrm{MA}$ and subjected to electrophoresis. The radioactivity was found to be associated only with $\alpha 2-\mathrm{M}-\mathrm{MA}$ (fast-moving form). No binding of ${ }^{125}$ I-leptin to native $\alpha 2-\mathrm{M}$ (slow-moving form) was observed. The complex formation was found to proceed rather fast: within 30 min of incubation approximately 70 to $80 \%$ of maximum binding was reached (results not shown).

Leptin- $\alpha 2-\mathrm{M}$ complexes were also detectable by Western blotting using polyclonal antibodies directed against leptin (Fig. 3). In the absence of SDS, leptin immunoreactivity was found to be associated with $\alpha 2$ M-MA. Free leptin, which was not bound, appeared as a diffuse band as it tends to aggregate under this electrophoretic condition. The complex was found to dissociate by treatment with SDS under nonreducing conditions. The bound leptin was released and moved as free leptin in SDS-PAGE.

To evaluate the binding affinity between ${ }^{125}$ I-leptin and $\alpha 2-\mathrm{M}-\mathrm{MA}$, the extent of complex formation under increasing concentrations of unlabeled leptin was

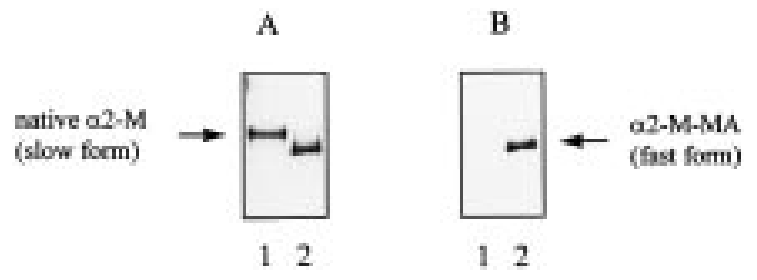

Figure 2 Binding of ${ }^{125}$ I-leptin to $\alpha 2-\mathrm{M}$, analyzed by rate electrophoresis and autoradiography. ${ }^{125}$ I-leptin (50 000 c.p.m.) was incubated at $37^{\circ} \mathrm{C}$ for 30 min with different samples. (A) Lane 1: $50 \mu$ l PBS containing $100 \mu \mathrm{g}$ of native $\alpha 2-\mathrm{M}$; lane 2: $50 \mu$ l PBS containing $100 \mu \mathrm{g}$ of $\alpha 2-\mathrm{M}-\mathrm{MA}$. Aliquots of $5 \mu \mathrm{l}$ were subjected to separation by rate electrophoresis. (A) Staining for protein; (B) autoradiography of samples from $(A)$. assessed, with separation of free and bound leptin by rate electrophoresis (Fig. 4). The radioactivity associated with the fraction of $\alpha 2-\mathrm{M}-\mathrm{MA}$ was measured in the gel. The $K_{\mathrm{d}}$ was calculated to be $2.14 \pm 0.78 \mu \mathrm{mol} / \mathrm{l}$. When the binding studies were done with MA-plasma under similar conditions, a $K_{\mathrm{d}}$ of $3.92 \pm 1.4 \mu \mathrm{mol} / \mathrm{l}$ was obtained, which is of the same order of magnitude compared with the purified inhibitor. As an example, the competing effect of unlabeled leptin on complex formation at a concentration of $4.16 \mu \mathrm{mol} / \mathrm{l}$ is shown in the inset of Fig. 4. The ability to displace the radiolabeled leptin by unlabeled leptin indicates that the hormone is bound to specific binding sites in the inhibitor molecule.

To analyze whether leptin, when bound to $\alpha 2-\mathrm{M}-\mathrm{MA}$, is still immunologically detectable, the leptin concentration was determined in fresh plasma and in the same plasma after reacting with MA. As seen in Table 1, no significant differences in leptin concentration could be observed in plasma before and after treatment with MA. The results indicate that leptin which is bound to $\alpha 2-\mathrm{M}-$ MA is not excluded from immunological reaction with antibodies used in our assay.

The complex between leptin and $\alpha 2-\mathrm{M}-\mathrm{MA}$ was found to be recognized by the receptor for $\alpha 2-\mathrm{M}$ (Fig. 5). As seen, $\alpha 2-\mathrm{M}-\mathrm{MA}$ increasingly binds to immobilized $\alpha 2-$ M-R/LRP in a saturable fashion. When analyzed for leptin, the binding curve parallels that of $\alpha 2-\mathrm{M}-\mathrm{MA}$, indicating that leptin does not dissociate from the inhibitor during receptor binding. In the presence of EDTA neither $\alpha 2-\mathrm{M}-\mathrm{MA}$ nor leptin was found to be bound to the receptor. It was confirmed by control experiments that leptin itself did not bind to $\alpha 2-\mathrm{M}-\mathrm{R} / \mathrm{LRP}$ and had no effect on the interaction between $\alpha 2-\mathrm{M}-\mathrm{MA}$ and the receptor.

The effect of increasing concentrations of $\alpha 2-\mathrm{M}_{\mathrm{t}}$ on leptin level in blood was qualitatively analyzed in terms of a skeleton model comprising both the transformation of $\alpha 2-\mathrm{M}$ and the receptor-mediated endocytosis of the 
A

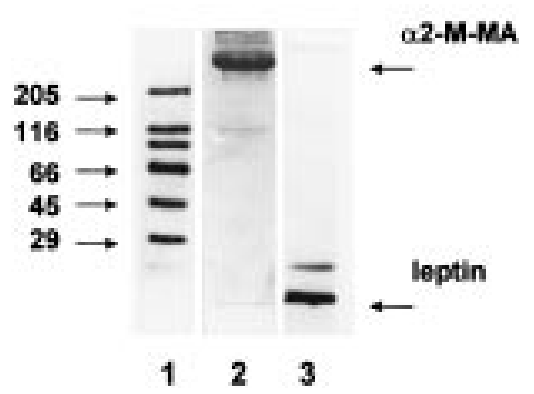

B

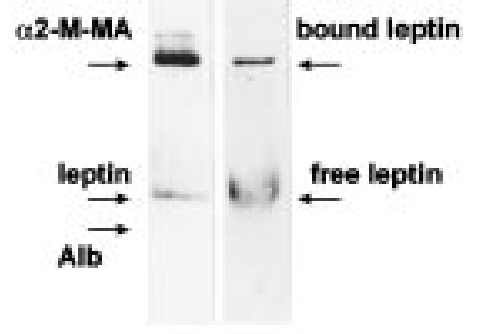

12

Figure 3 Immunodetection by Western blotting of leptin- $\alpha 2-\mathrm{M}-\mathrm{MA}$ complexes. One hundred $\mu \mathrm{g}$ of $\alpha 2-\mathrm{M}-\mathrm{MA}$ was incubated with $1.5 \mathrm{molar}$ excess of leptin $(3.3 \mu \mathrm{g})$ in $100 \mu \mathrm{l}$ PBS at $37{ }^{\circ} \mathrm{C}$ for $30 \mathrm{~min}$. Aliquots of $20 \mu \mathrm{l}$ were subjected to PAGE in $3-15 \%$ pore gradients in the presence $(A)$ and absence $(B)$ of SDS. The proteins were transferred to nitrocellulose membranes (Schleicher \& Schuell, Dassel, Germany), blocked with defatted milk ( $3 \%$ in PBS), and finally incubated with rabbit anti-human leptin $\mathrm{lg}(1 \mu \mathrm{g} / \mathrm{ml})$, and HRP-conjugated goat anti-rabbit Ig for $2 \mathrm{~h}$, each. Band visualization was achieved using the substrates diaminobenzidine and $\mathrm{H}_{2} \mathrm{O}_{2}$. Protein staining with Coomassie Blue R 250 (A, lane 1 and 2) and (B, lane 1); immunodetection of leptin by Western blotting (A, lane 3) and (B, lane 2). Molecular mass marker proteins used: (A) carbonic anhydrase (29kDa), ovalbumin ( $45 \mathrm{kDa})$, albumin $(66 \mathrm{kDa})$, $\beta$-galactosidase $(116 \mathrm{kDa})$ and myosin $(205 \mathrm{kDa})$. (B) The migration of leptin relative to albumin indicates aggregation of free leptin under those conditions.

leptin- $\alpha 2-\mathrm{M}_{\mathrm{t}}$ complex (Fig. 6). Using quite plausible assumptions about the endocytosis rate constant of the $\alpha 2-\mathrm{M}_{\mathrm{t}}$ and the $K_{\mathrm{d}}$ of the leptin- $\alpha 2-\mathrm{M}_{\mathrm{t}}$ complex, we could demonstrate that the stationary leptin level drops significantly if the blood concentration of $\alpha 2-\mathrm{M}_{\mathrm{t}}$ increases. For calculation, the variation of $\alpha 2-\mathrm{M}_{\mathrm{t}}$ was achieved by changing the rate of transformation. However, similar results could be obtained by varying the rate constant for the endocytosis of $\alpha 2-\mathrm{M}_{\mathrm{t}}$ and/or of the leptin- $\alpha 2-\mathrm{M}$ complex.

\section{Discussion}

In the present study we present evidence that human leptin specifically binds to the $\alpha 2-\mathrm{M}_{\mathrm{t}}$. No significant binding of leptin to native $\alpha 2-\mathrm{M}$ was found. The $K_{\mathrm{d}}$ value of $2.14 \mu \mathrm{mol} / \mathrm{l}$ obtained for the leptin binding to the purified inhibitor was found to be similar to that obtained for the interaction in whole plasma, indicating that other serum proteins did not significantly interfere with this binding.

Leptin binding to $\alpha 2-\mathrm{M}$ was found to be stable during chromatographic and electrophoretic separation but did not resist treatment by SDS. This gives rise to the assumption that the binding is probably conferred by hydrophobic interactions. The presence of hydrophobic binding sites in $\alpha 2-\mathrm{M}_{\mathrm{t}}$ has been described earlier (19). It becomes evident, from our experiments, that the binding to $\alpha 2-\mathrm{M}_{\mathrm{t}}$ of leptin is reversible, involves very specific sites and is different from that known for binding of proteinases to the inhibitor $(20,21)$.

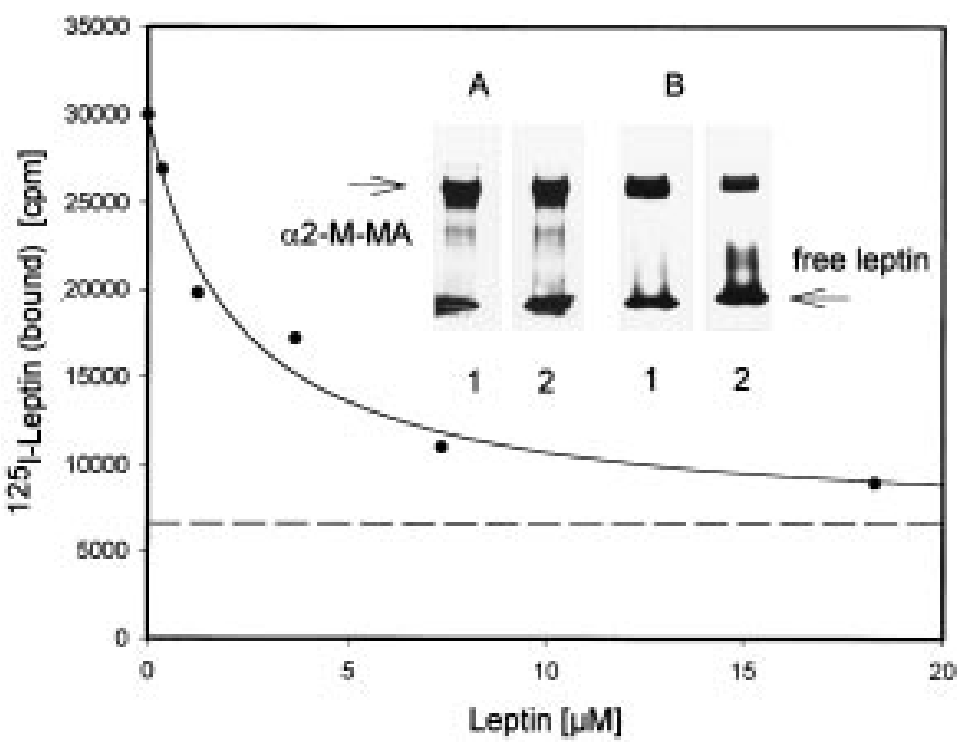

Figure 4 Displacement of ${ }^{125}$-leptin binding to $\alpha 2-\mathrm{M}$ MA by unlabeled leptin. Samples of $100 \mu \mathrm{g}$ of $\alpha 2-\mathrm{M}$ MA were mixed with ${ }^{125}$-leptin (200000 c.p.m.) and increasing concentrations of unlabeled leptin in a total volume of $85 \mu \mathrm{l}$, and were incubated at $37^{\circ} \mathrm{C}$ for $30 \mathrm{~min}$. Then aliquots $(17 \mu \mathrm{l})$ of the samples were subjected to rate electrophoresis. After gel drying and autoradiography, the protein bands were cut from the gel and subjected to $\gamma$-counting to determine that fraction of leptin bound to $\alpha 2-\mathrm{M}-\mathrm{MA}$. Nonlinear regression analysis was applied to calculate the $K_{d}$. The radioactivity (c.p.m.) associated with $\alpha 2-\mathrm{M}-\mathrm{MA}$ is expressed on the ordinate; the abscissa indicates the concentration of unlabeled leptin in the incubation mixture. Inset: (A) Coomassie Blue staining of a sample containing $20 \mu \mathrm{g}$ of $\alpha 2-\mathrm{M}-\mathrm{MA}$ and ${ }^{125}$-leptin (lane 1); $20 \mu \mathrm{g}$ of $\alpha 2-\mathrm{M}-\mathrm{MA},{ }^{125}$ I-leptin, and $4.16 \mu \mathrm{mol} /$ I unlabeled leptin (lane 2). (B) Autoradiography of samples from $(A)$. 
Table 1 Effect of transformation of $\alpha 2-\mathrm{M}$ on determination of leptin concentration in plasma. Aliquots of plasma obtained from a lean person were treated with MA to transform $\alpha 2-\mathrm{M}$. The concentrations $\left( \pm\right.$ S.D.) of total $\alpha 2-\mathrm{M}, \alpha 2-\mathrm{M}_{\mathrm{t}}$, and leptin were determined in untreated and MA-treated plasma by ELISA. The given concentrations are the means of triplicate determinations.

\begin{tabular}{llll}
\hline Specimen & $\begin{array}{l}\text { Total } \alpha 2-\mathbf{M} \\
(\mathrm{mg} / \mathrm{ml})\end{array}$ & $\begin{array}{l}\alpha 2-\mathbf{M}_{\mathrm{t}}{ }^{*} \\
(\mathrm{mg} / \mathrm{ml})\end{array}$ & $\begin{array}{l}\text { Leptin } \\
(\mathrm{ng} / \mathrm{ml})\end{array}$ \\
\hline Plasma & $1.28 \pm 0.05$ & $0.0057 \pm 0.0003$ & $6.21 \pm 0.2$ \\
MA-plasma & $1.29 \pm 0.05$ & $1.30 \pm 0.06$ & $6.31 \pm 0.3$
\end{tabular}

${ }^{*} \alpha 2-\mathrm{M}_{\mathrm{t}}$ means transformed $\alpha 2-\mathrm{M}$ as measured by the MacroTrans test kit.

At present, it is commonly assumed that leptin circulates in plasma in a free form and bound to proteins. However, no proteins could be identified so far fulfilling this function in animal and human plasma. Candidates have been described with molecular masses ranging from 85 to $240 \mathrm{kDa}$ (5). There are also indications that a putative soluble leptin receptor $(\approx 90 \mathrm{kDa})$ may form such complexes with leptin in plasma (6). Diamonds et al. (7) described a high molecular mass component $(>450 \mathrm{kDa})$ of unknown identity which competitively bound leptin in human serum.

From our results it can be concluded that it is very important to know about the concentrations of total and $\alpha 2-\mathrm{M}_{\mathrm{t}}$ in the samples when comparing results of leptin binding studies by different authors. This is because the fraction of transformed inhibitor in blood increases with sample storage and frequent freezing and thawing (22). Furthermore, when serum instead of plasma is used, about 20 to $30 \%$ of the inhibitor is already transformed. All that may have a significant impact on the distribution of leptin in blood specimens.

It is known that some proteins, when bound to $\alpha 2-\mathrm{M}$, become caged and escape immunological detection (21). Such an interference would have a significant impact on the determination of leptin levels in blood. Our results demonstrate that even in the case when all $\alpha 2-\mathrm{M}$ in plasma is transformed, no loss in leptin concentration was observed. This indicates that the leptin-binding site(s) may be located at the surface of the inhibitor molecule accessible to anti-leptin antibodies. However, it cannot be excluded that, due to the low affinity of leptin for $\alpha 2-\mathrm{M}_{\mathrm{t}}$, leptin may dissociate from the complex in the presence of the high affinity antibody, which may be the reason why $\alpha 2-\mathrm{M}$ does not interfere with the leptin assay.

We have shown that the leptin- $\alpha 2-\mathrm{M}_{\mathrm{t}}$ complex is recognized by the $\alpha 2-\mathrm{M}-\mathrm{R} / \mathrm{LRP}$. Recognition is conveyed via the receptor-recognition site located on the $\mathrm{C}$ terminal part of the polypeptide chain of $\alpha 2-\mathrm{M}_{\mathrm{t}}$. The fact that leptin binding did not interfere with receptor recognition indicates the existence of separate binding sites in the inhibitor. The clearance of $\alpha 2-\mathrm{M}_{\mathrm{t}}$ from the circulation by $\alpha 2-\mathrm{M}-\mathrm{R} / \mathrm{LRP}$ occurs very fast, with a halflife of approximately $5 \mathrm{~min}$. Under normal conditions, the concentration of $\alpha 2-\mathrm{M}_{\mathrm{t}}$, capable of leptin binding, in plasma is approximately $7 \mathrm{nmol} / \mathrm{l}$, which is, however, about 20 times higher than that of leptin in lean patients. Additionally, that fraction can very quickly increase by proteolytic transformation from the large pool of native $\alpha 2-\mathrm{M}(3.5 \mu \mathrm{mol} / \mathrm{l})$ present in the circulation (22). This would suggest that $\alpha 2-\mathrm{M}$ and its

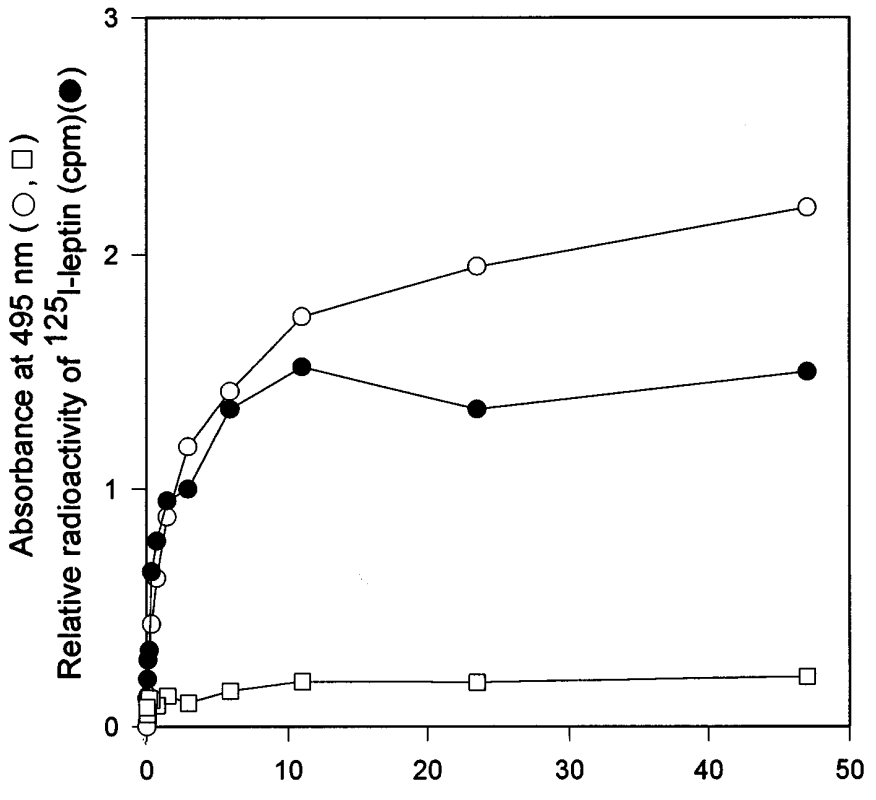

Concentration of transformed $\alpha 2$-macroglobulin (nM)
Figure 5 Binding of the leptin- $\alpha 2-M-M A$ complexes to immobilized $\alpha 2-M-R / L R P$. Titer plates were coated with $\alpha 2$ $\mathrm{M}-\mathrm{R} / \mathrm{LRP}(2 \mu \mathrm{g} / \mathrm{ml})$ and blocked with $1 \%$ BSA. Increasing concentrations of ${ }^{25}$ I-leptin- $\alpha 2-\mathrm{M}-\mathrm{MA}$ complex were allowed to react with the receptor at $37^{\circ} \mathrm{C}$ for $3 \mathrm{~h}$ in binding buffer $\left(20 \mathrm{mmol} / \mathrm{l}\right.$ Hepes, $\left.150 \mathrm{mmol} / \mathrm{NaCl}, 5 \mathrm{mmol} / / \mathrm{Ca}^{2+}\right)$. Then the plates were washed and the bound $\alpha 2-\mathrm{M}-\mathrm{MA}$ was detected immunologically by incubating with polyclonal anti- $\alpha 2-\mathrm{M}-\mathrm{lg}-$ $\mathrm{HRP}$ at $37^{\circ} \mathrm{C}$ for $1 \mathrm{~h}$. After washing, the reaction was visualized using diaminobenzidine/ $\mathrm{H}_{2} \mathrm{O}_{2}$ as substrates. For determination of bound radiolabeled leptin, the ${ }^{125}$-leptin- $\alpha 2$ M-MA complex was dissociated from the immobilized receptor in a parallel experiment by addition of $200 \mu$ l of $0.7 \%$ SDS, $1 \mathrm{~mol} / / \mathrm{NaOH}$ at $37^{\circ} \mathrm{C}$ for $3 \mathrm{~h}$. The radioactivity which was released was then determined by $\gamma$-counting. The binding of the leptin- $\alpha 2-\mathrm{M}-\mathrm{MA}$ complex to immobilized receptor in buffer containing $50 \mathrm{mmol} / /$ EDTA was taken as the control for binding specificity. $(O)$ Binding curve of leptin$\alpha 2-\mathrm{M}-\mathrm{MA}$ complex analyzed by antibodies against $\alpha 2-\mathrm{M} ;(\bullet)$ binding curve of ${ }^{125}$ I-leptin- $\alpha 2-M-M A$ analyzed by $\gamma$-counting; ( $\square$ ) binding curve of leptin- $\alpha 2-M-M A$ complex in the presence of $50 \mathrm{mmol} / /$ EDTA analyzed by antibodies against $\alpha 2-\mathrm{M}$. 

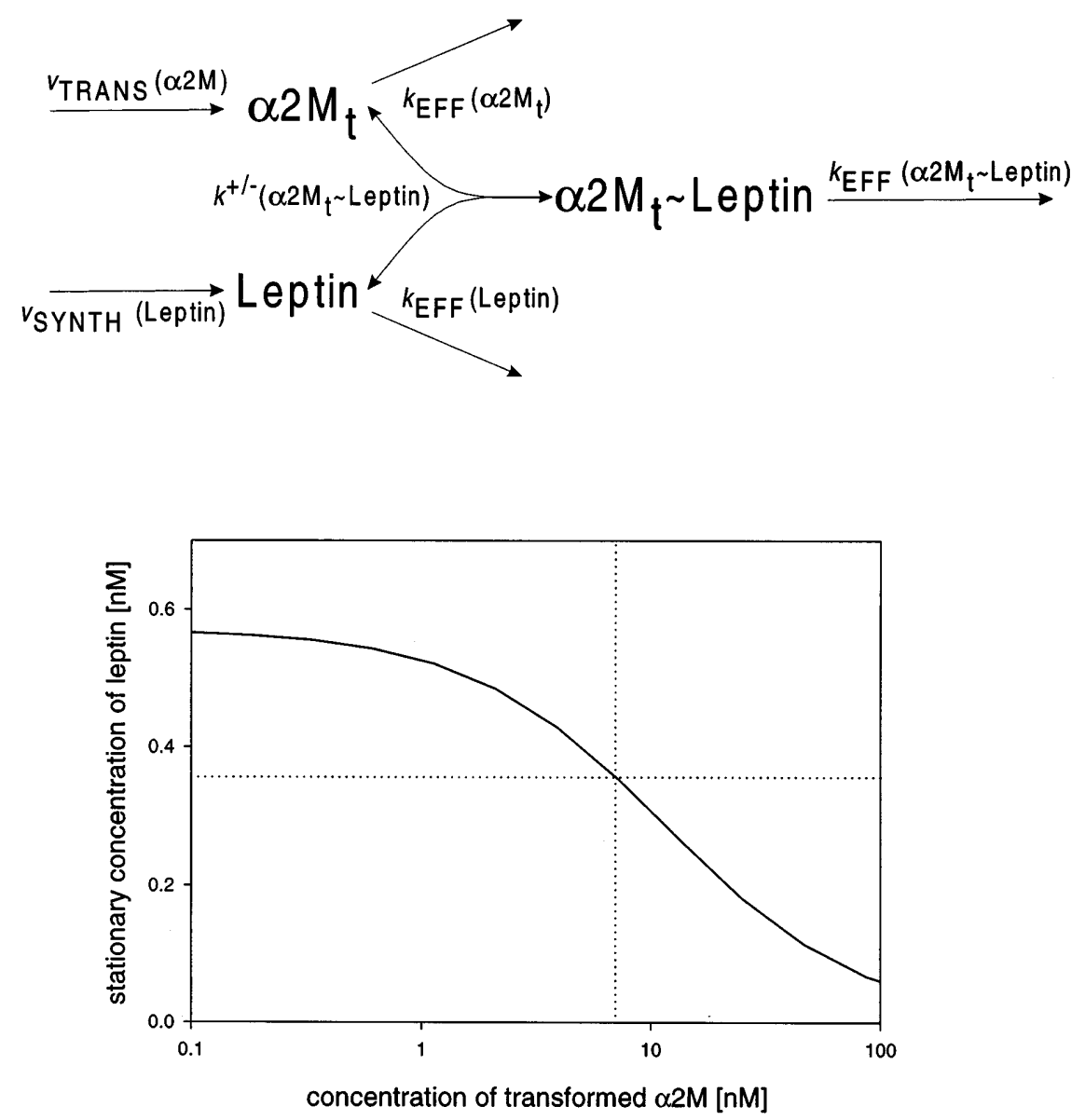

Figure 6 Computer simulation of the impact on leptin concentration of increasing transformation of $\alpha 2-\mathrm{M}$. Upper: skeleton scheme describing the diminishing effect of $\alpha 2-\mathrm{M}$ transformation on the quasi-stationary leptin concentration. Lower: the stationary level of leptin depends on the concentration of $\alpha 2-\mathrm{M}_{\mathrm{t}}$. The curve was obtained by changing the rate of transformation of $\alpha 2-\mathrm{M}:\left(\mathrm{v}_{\text {TRANS }}(\alpha 2-\mathrm{M})=\right.$ $\left.0.2 \ldots 20 \mathrm{nmol} / / \times \mathrm{min}^{-1}\right)$. Constants used for simulation: $\mathrm{v}_{\mathrm{SYNTH}}($ leptin $)=0.1 \mathrm{nmol} / \mathrm{l} \times \mathrm{min}^{-1} ; \mathrm{k}^{+}\left(\alpha 2-\mathrm{M}_{\mathrm{t}}\right.$-leptin $) / \mathrm{k}^{-}\left(\alpha 2-\mathrm{M}_{\mathrm{t}}\right.$-leptin $)=$ $2.14 \mu \mathrm{mol} / / ; \mathrm{k}_{\mathrm{EFF}}(\alpha 2-\mathrm{M})=0.1 / \mathrm{min} ; \mathrm{k}_{\mathrm{EFF}}\left(\alpha 2-\mathrm{M}_{\mathrm{t}}\right.$-leptin $)=1 / \mathrm{min}$. $\left(\alpha 2-\mathrm{M}_{\mathrm{t}}\right.$ designates transformed $\alpha 2-\mathrm{M}$ which in blood is created by proteinases and not by methylamine).

receptor may effectively modulate the concentration of leptin in blood, and thus in brain, as leptin is known to cross the blood-brain barrier. It is well known that $\alpha 2-\mathrm{M}$ binds and carries a number of cytokines and growth factors. Thus, by triggering the transformation as induced by inflammation, tissue remodeling, cell invasion etc., $\alpha 2-\mathrm{M}$ may play an unique role in mediating metabolic effects in different directions. At present, it is generally assumed that the hallmark of obesity in humans is leptin resistance, but not the absence of leptin. Leptin resistance could result from alterations in leptin receptor expression or receptor binding, from a disabled transport mechanism via the blood-brain barrier, or from alterations in the bioavailability or bioactivity of circulating leptin. Thus, complex formation with binding proteins may possibly restrict the availability of free leptin for its inhibitory effect on food intake. On the other hand, a decreased clearance of leptin may lead to an increased concentration of circulating leptin. Recently, a mutation in the human leptin receptor gene was detected which causes a significant shift in the distribution of leptin in the plasma of homozygous patients (23). Compared with controls, approximately $80 \%$ of leptin was found to circulate as a high molecular mass complex (<440 kDa) in plasma. Binding to a soluble dimeric leptin receptor was discussed in that paper, but the large mass of the complex found may not fit that assumption. Our preliminary results indicate that both $\alpha 2-\mathrm{M}$ and $\alpha 2$ M-R/LRP are likely to be involved in binding and clearance of leptin. To analyze this may be a potential topic of future research.

\section{References}

1 Zhang Y, Proenca R, Maffei M, Barone M, Leopold L \& Friedmann JM. Positional cloning of the mouse obese gene and its human homologue. Nature 1991372 425-432. 
2 Pelleymounter MA, Cullen MJ, Baker MB, Hecht R, Winters D Boone $\mathrm{T}$ et al. Effects of the obese gene product on weight regulation in ob/ob mice. Science 1995269 540-543.

3 Rohner-Jeanrenaud F, Cusin I, Sainsbury A, Zakrzewska KE \& Jeanrenaud B. The loop system between neuropeptide Y and leptin in normal and obese rodents. Hormone and Metabolic Research $199628642-648$.

4 Caro JF, Kolaczynski JW, Nyce MR, Ohannesian JP, Opentanova I, Goldman WH et al. Decreased cerebrospinal-fluid/serum leptin ratio in obesity: a possible mechanism for leptin resistance. Lancet $1996348159-161$.

5 Houseknecht KL, Mantzoros CS, Kuliawat R, Hadro E, Flier JS \& Kahn BB. Evidence for leptin binding to proteins in serum of rodents and humans: Modulation with obesity. Diabetes 199645 $1638-1643$.

6 Sinha MK, Opentanova I, Ohannesian JP, Kolaczynski JW, Heiman ML, Hale J et al. Evidence of free and bound leptin in human circulation. Journal of Clinical Investigation 199698 1277-1282.

7 Diamond FB, Eichler DC, Duckett G, Jorgensen EV, Shulman D \& Root AW. Demonstration of a leptin binding factor in human serum. Biochemical and Biophysical Research Communications 1997 $233818-822$

8 Clemmons DR. Insulin like-growth factor binding proteins. Role in regulating IGF physiology. Journal of Developmental Physiology 199115 105-110.

9 Borth W. Alpha 2-macroglobulin, a multifunctional binding protein with targeting characteristics. FASEB Journal 19926 3345-3353.

10 Kratzsch J, Selisko T \& Birkenmeier G. Identification of transformed $\alpha 2$-macroglobulin as a growth hormone-binding protein in human blood. Iournal of Clinical Endocrinology and Metabolism 199580 585-590.

11 Herz J, Hamann U, Rogne S, Myklebost O, Gausepohl H \& Stanley KK. Surface location and high affinity for calcium of a 500-kD liver membrane protein closely related to the LDL receptor suggest a physiological role as lipoprotein receptor. EMBO Journal 19887 4119-4127.

12 Strickland DK, Ashcom JD, Williams S, Burgess WH, Migliorini M $\&$ Argraves WS. Sequence identity between $\alpha 2$-macroglobulin receptor and low density lipoprotein receptor related protein suggests that this molecule is a multifunctional receptor. Journal of Biological Chemistry 1990265 17401-17404.
13 Beisiegel U, Weber W, Ihrke G, Herz J \& Stanley KK. The LDLreceptor-related protein, LRP, is an apolipoprotein E-binding protein. Nature 1989341 162-164.

14 Strickland DK, Kounnas MZ \& Argraves WS. LDL receptor-related protein: a multiligand receptor for lipoprotein and proteinase catabolism. FASEB Journal 19959 890-898.

15 Hunter WM \& Greenwood FC. Preparation of iodine-131 labeled human growth hormone of high specific radioactivity. Nature $1962194495-496$.

16 Van Leuven F, Cassiman J-J \& Van den Berghe H. Functional modifications of $\alpha 2$-macroglobulin by primary amines. Journal of Biological Chemistry $19812569016-6022$.

17 Laemmli UK. Cleavage of structural proteins during the assembly of the of bacteriophage $\mathrm{T}_{4}$. Nature $1970227680-685$.

18 Mendes, P. GEPASI: a software package for modelling the dynamics, steady states and control of biochemical and other systems. Computer Applications in the Biosciences 19939 563571.

19 Birkenmeier G, Carlsson-Bostedt L, Shanbhag V, Kriegel T, Kopperschläger G, Sottrup-Jensen L et al. Differences in hydrophobic properties for $\alpha 2$-macroglobulin and pregnancy zone protein as studied by affinity phase partitioning. European Journal of Biochemistry 1989183 239-243.

20 Sottrup-Jensen L. Alpha 2-macroglobulins: structure, shape, and mechanism of proteinase complex formation. Journal of Biological Chemistry 1989264 11539-11542.

21 Otto A, Bär J \& Birkenmeier G. Prostate-specific antigen forms complexes with human alpha 2-macroglobulin and binds to the alpha 2-macroglobulin receptor/LDL receptor-related protein. Journal of Urology 1998159 297-303.

22 Birkenmeier G \& Stigbrand T. Production of conformation-specific monoclonal antibodies against $\alpha 2$-macroglobulin, and their use for quantitation of total and transformed $\alpha 2$-macroglobulin in human blood. Journal of Immunological Methods 199362 5967.

23 Clement K, Vaisse C, Lahlou N, Cabrol S, Pelloux V, Cassuto D et al. A mutation in the human leptin receptor gene causes obesity and pituitary dysfunction. Nature 1998392 398-401.

Received 17 February 1998

Accepted 30 April 1998 